\title{
The relationship between spiritual health and mental health in students of Kurdistan University of Medical Sciences
}

\author{
Fayegh Yousefi ${ }^{1}$, Sahar Rafiee $^{2}$, Fariba Tairi $^{3}$
}

1-Associate Professor, Spiritual Health Research Center, Research Institute for Health Development, Kurdistan University of Medical Sciences, Sanandaj, Iran. ORCID: 0000-0001-5503-3326

2- Master clinical psychology, Faculty of Medicine, Kermanshah University of Medical Sciences, Kermanshah, Iran. ORCID:

3- M.Sc in clinical psychology, Vice Chancellor for Student and Cultural Affairs, Student Counseling Center, Kurdistan University of Medical Sciences, Sanandaj, Iran (Corresponding Author). ORCID: 0000-0002-0203-8219

E-mail: Faribafaran94@gmail.com

Received: 24/04/2019

Accepted: 08/09/2019

\begin{abstract}
Introduction: The spiritual health is the most important socio-cultural factors that related to mental health.

Aim: The aim of this study was to determine the relationship between mental health and spiritual health in students of Kurdistan University of Medical Sciences in 2014.

Method: The study was descriptive- correlative. The participants were of 436436 freshman students. The questionnaires includes demographic information, Palutzian Spiritual Health Questionnaire (20 item) that 10 questions measure religious health and 10 questions measure existential health. mental health was measured by GHQ-28 ( somatic symptoms, anxiety symptoms, the symptoms of social dysfunction and depression)with cutoff point of 23. Data were analyzed, by using 22 SPSS statistical software and Pearson correlation, t-test and one way ANOVA.

Results: $63 / 5 \%$ of student were female and $91 / 7 \%$ of the student were single. Nearly $72 \%$ were t20-18 years. 58/9\% of the participants were native.67/3\% have high spiritual health, 95/2\% with high religious health and84/2\% have elevated their health.87/2\% of participants had sufficient mental health and $12 / 8 \%$ were suspected of mental vulnerability. Although there was a significant relationship between religious health and health with mental health (P $0<001)$.

Conclusion: The higher spiritual health, psychological trauma will be less. In other words, we can use the spiritual health of the students as a predictor of mental crisis in them.

Keywords: Health, Spiritual health, Religious health, Existential health, Psychosocial health, Students

How to cite this article : Yousefi F, Rafiee S, Tairi F. The relationship between spiritual health and mental health in students of Kurdistan University of Medical Sciences. Shenakht Journal of Psychology and Psychiatry. 2019; 6 (4): 100-109 .URL: http://shenakht.muk.ac.ir/article-1-
\end{abstract} 799-fa.pdf

Copyright $(92018$ the Author (s). Published by Kurdistan University of Medical Sciences. This is an open access article distributed under the terms of the Creative Commons Attribution-Non Commercial License 4.0 (CCBY-NC), where it is permissible to download, share, remix, transform, and buildup the work provided it is properly cited. The work cannot be used commercially without permission from the journal. 


\section{بروسى سلامت معنوى و ارتباط آن با سلامت روان در دانشجويان جديدالورود دانشكاه علوم يزشكى كردستان}

\section{فايق يوسفى'، سحر رفيعى'، فريبا طيرى؟}

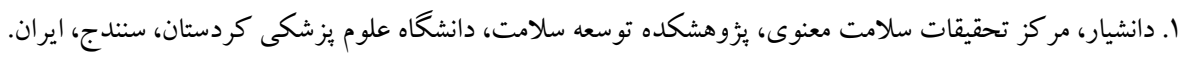

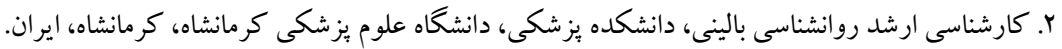

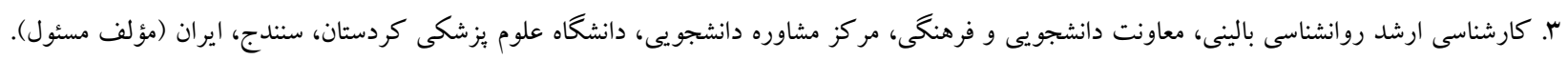
ايميل: faribafaran94@gmail.com هدف: هدف از مطالعه حاضر تعيين ارتباط بين سلامت روان و سلامت معنوى در دانشجويان دانشكاه علوم بزشكى كردستان بود كه در سال هوف: هدا انجام گرديد.

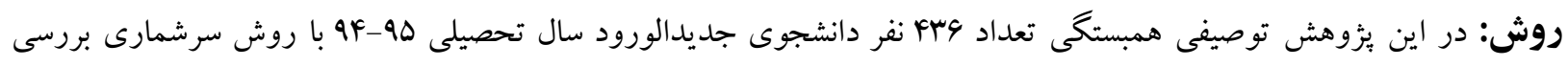

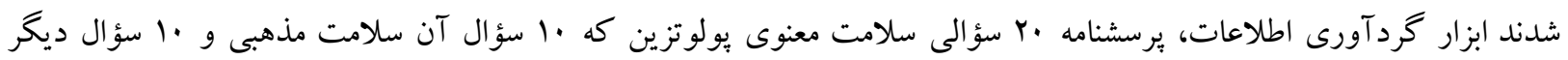
سلامت وجودى را اندازه گيرى مى كرد و آزمون سلامت روان GHQ-28 كه جهار مقياس علائم جسمانى، علائم اضطر ابى، علائم

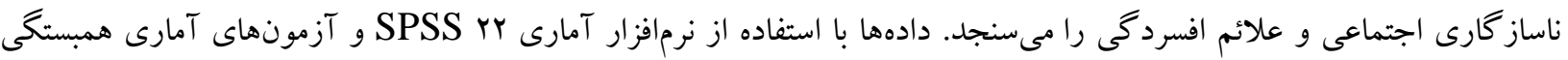
بيرسون، تى تست و آنوا استفاده شد.

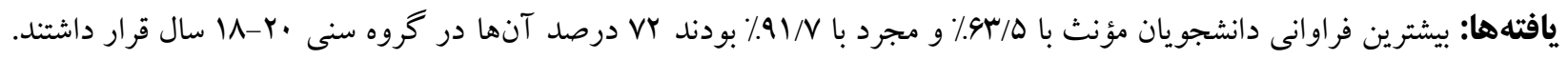

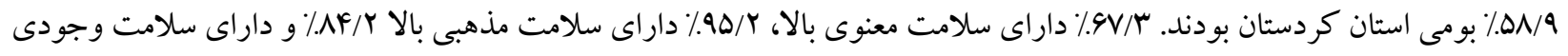

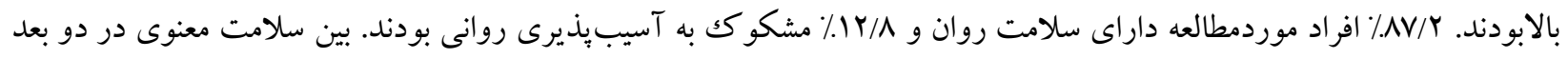
سلامت مذهبى و سلامت وجودى با سلامت روان آنان رابطه معنادارى وجود داشت. نتيجه كيرى: هرجه ميزان سلامت معنوى در دانشجويان بالاتر باشد، ميزان آسيبهاى روانى در آنها كمتر خواهد بود. به

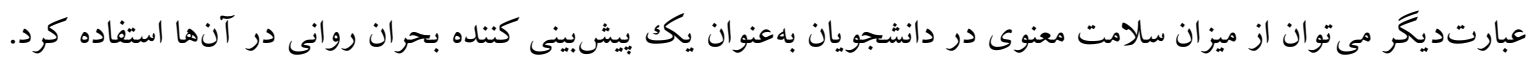
كليدوازه: سلامت معنوى، سلامت مذهبى، سلامت وجودى، سلامت روانى، دانشجويان 
همكاران،1/(Y). برخى معتقدند معنويت فراتر از مذهب

و شامل مفاهيم ديخرى همجيون سلامت معنوى، آرامش و راحتى ناشى از ايمان و تطابق معنوى، تجربيات و تظاهرات روح فرد در يككروند بىهمتا و ديناميكك كه منعكس كننده ايمان به خدا يا يكك قدرت بىنهايت است، همجنين دربر گيرندهى اتصال به يكك فرد، ديكران،

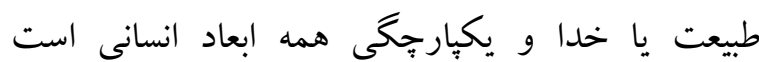

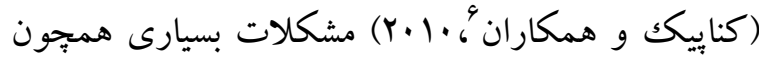
ابهام در تعريف سلامت معنوى، عدم توافق كلى بر مفاهيم اساسى مربوط به مسئله، عدم تبيين مرزهاى سلامت معنوى و معنويت، عدم دستيابى به ابزارهاى مناسب جهت سنجش سلامت معنوى عدم طراحى صحيح سؤالات، سنجش ديخر حيطهاى سلامت، عدم اعتبار و يايايى برخى ابزارهاى سنجش و ...و استفاده از نمونهاى

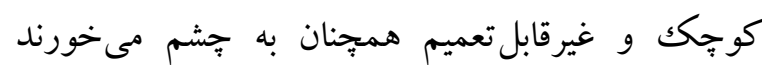

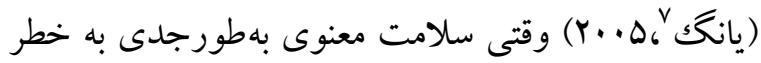

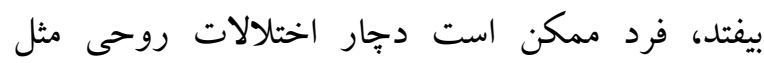

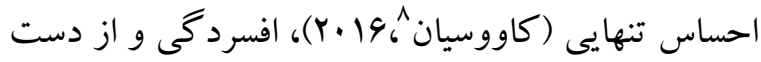
دادن معنا در زندگى شود (سدرى، +.بr). در اين ميان سلامت معنوى به شكل برجستهاى در متون دينى موردتوجه قرار گرفته، اسلام وجود آدمى را متشكل از دو لموله بعد روانى (غيرمادى) و جسمانى (مادى) معرفى مى كند. سلامت روان به معناى تعادل و انسجام فراگير در همه ابعاد جسمانى و نفسانى انسان است كه قلب سليم (شعرا1) و نفس مطمئنه (فجر YV) ازجمله علائم آن است و در مقابل، بيمارى روانى خارج شدن از حد اعتدال است كه امراض قلبى و اضطراب ازجمله نشانهاى آن است (مائده- -Or). از اثرات سلامت روانى مىتوان به موارد

${ }^{6}$. Knapik GP et al.

7. Young

${ }^{8}$. Kavoosian.
يكى از موضوعات مهم در ابعاد مختلف سلامتى، سلامت

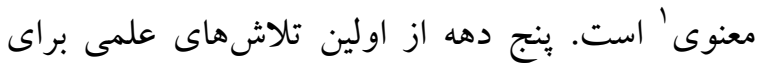
سنجش مفهوم سلامت معنوى كذشته است در دهلهاى قبل سلامتى و ابعاد آن به شكل كاهش گر ايانه اي محدود به ابعاد جسمانى مىشد اما رويكردهاى جديد بهسلامتى نغاه جامع و جندبعدى سلامت انسان دارند و سلامت را دربر گيرنده ابعاد جسمانى،روانى،اجتماعى و و معنوى

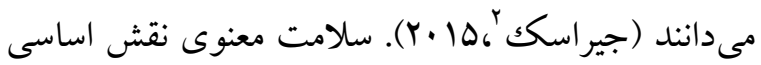
در ميان ديخر ابعاد سلامت دارد و توجه زياد يزوهشخران حوزه سلامت عمومى را جذب كرده است. به عبارتى تا سلامت معنوى جايگاه واقعى خود را در ميان مردم بيدا نكند انسان نمىتواند بهسلامت كامل دست يابد. (آديب

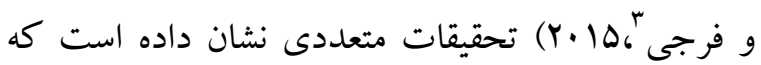
سلامت معنوى مىتواند در بهبود ساير مشكلات و و بيمارىهاى جسمانى و روانشناختى نقش تعديل كننده ايفا كند و بيامدهاى بيمارى را كاهش دهد (هيلتون و

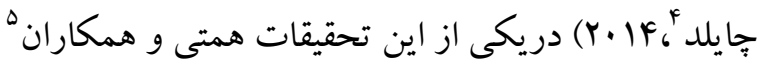
(Y) (Y) نشان دادند كه سلامت معنوى با سلامت جسمانى بهتر در ارتباط است و در افرادى كه سلامت معنوى بالاترى تجربه كردند احساس درد كمترى گزارش كردند. معانى بسيار مختلفى در مقالات و كتب كوناگون در مورد معنويت و سلامت معنوى ارائهدهاند. هنگام يرداختن به اين دو، مفهوم مذهب نيز به ميان مى آيد.

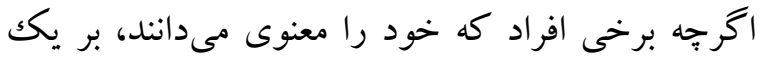

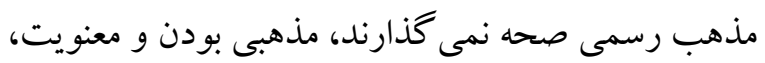

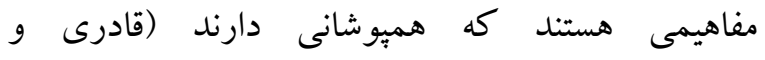

\footnotetext{
'. Spiritual health

2. Jirásek I.

${ }^{3}$. Adib-Hajbaghery M, Faraji M

${ }^{4}$. Hilton JM, Child SL.

${ }^{5}$. Hematti $\mathrm{S}$, et al.
} 


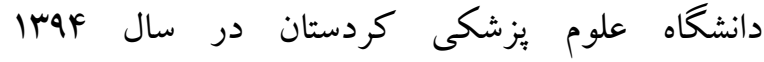
انجام خرفته است.

روش

يزوهش حاضر از نوع مطالعات توصيفى -تحليلى بوده كه بهصورت مقطعى در نيم سال دوم تحصيلى هو-9F انجام

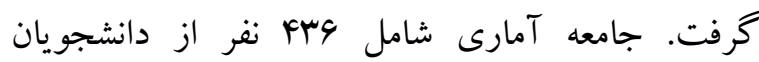
جديدالورود دانشگاه علوم يزشكى كردستان بودند كه به طريق نمونه گيرى سرشمارى، بهعنوان نمونه در نظر گرفته شدند. معيار ورود دانشجويان عبارت بود از جديدالورود بودن و تمايل به بِاسخگ يُ به سؤالات. ابتدا اطلاعات

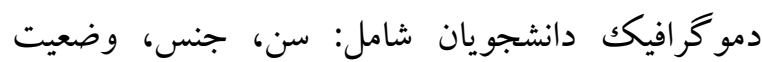
تأهل، بومى يا غيربومى بودن جمع آورى شد.

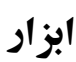

برسشنامه · ب سؤالى سلامت معنوى (يولوتزين و اليسون'

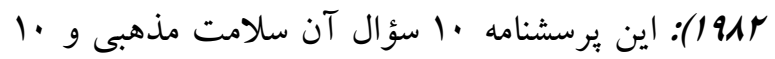
سؤال ديخر سلامت وجودى را اندازه گيرى مى كند. دامنه نمره سلامت مذهبى و وجودى، هر كدام به تفكيك .1. •4 بود. براى زيركروههاى سلامت مذهبى و وجودى، سطحبندى وجود نداشت و قضاوت بر اساس نمره بهدست آمده صورت كرفت. هرجه نمره بهدست آمده، بالاتر باشد نشانه سلامت مذهبى و وجودى بالاتر است. نمره سلامت معنوى، جمع اين دو زير كروه است كه

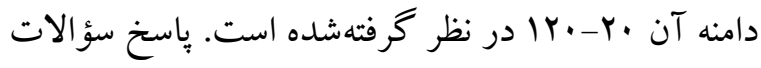
بهصورت ليكرت 4 گزينهاى از كاملاً مخالفم تا كاملاً مو افقم دستهبندى شد به كونهاى كه به گزينه كاملاً موفقم مقدار 9، موافقم مقدار ه، نسبتاً موافقم مقدارث، نسبتاً مخالفم مقدار سا، مخالفم مقدار r و كاملاً مخالفم مقدار 1
زير اشاره نمود: ا-|نسانى كه داراى روان سالم است، رويدادهايى كه بديد مى آيد، به آرامش روانى وى آسيب نمىزند، زيرا مىداند كه جهبسا وقايع ناخوشايند كه خير هستند و جهابسا امور دوستداشتنى كه شرند (بقره- (Y) r- مشكلات و سختىها را قرين و مقدمه آسايش و كشايش مىداند و همواره اميدوار است) طلاق V) و از رحمت خدا مأيوس نيست (يونس AV) بيرو ظن و گمان نيست و از بد كمانى برهيز مى كند، زيرا بد گمانى را گُناه مى ماند.ب-افسردگى و اضطراب ندارد و از احساس امنيت و آرامش برخوردار است و ترس و غم و اندوه را در دل

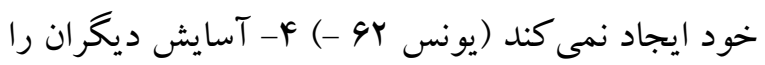
برآسايش خود مقدم مىداند و ازاينرو است كه سخاوتمند و دستودلباز است (حشره ) ه- به ديخران نيكى مى كند و نيكى ديخران را با نيكى بالاترى ياسخ

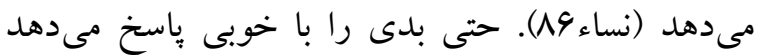
(نحل وبr|) اكر به كسى نيكى كرد او را با منت نمى آزارد و منّت كذار و فزونطلب نيست (مدثر و. قر آن كريم). يكى از بيامدهاى گرايش به تطبيق روشهاى علوم تجربى در حوزه يزوهش روانشناسى اين بود كه تنها به يديدهاى روانى ناشى از فعاليتهاى فيزيولوزى بسنده شد و بعد معنوى و حقيقت انسان در يثزوهشها به دست فراموشى سبرده شد؛ ازاينرو از تحقيق درباره مسئله عشق، محبت و مانند آن بازماندند و از بحث در مورد كيفيت هماهنكى ميان شخصيت انسان از طريق ايجاد توازن ميان جنبههاى مادى و معنوى او و موضوعات ديخرى ازايندست كنار كذاشته شد (حسينى، 1990) بر اين اساس و با توجه به خلأ بُزوهشى در اين حوزه بهويزه در ميان دانشجويان اين يزوهش باهدف بررسى رابطه بين سلامت روانى و سلامت معنوى در بين دانشجويان

\footnotetext{
${ }^{1}$. Palutzian \& Ellison
} 
پايينتر از آن از سلامت روانى برخوردار بودند. روايى "ِرسشنامها پِس از ترجمه به فارسى از طريق اعتبار محتوا تعيين گرديد. بايايى برسشنامه سلامت معنوى در مطالعه

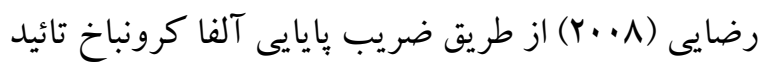

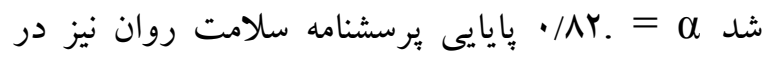

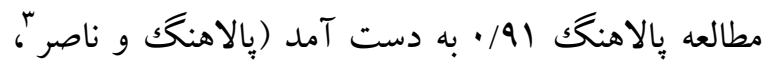
(199V ) قبل از توزيع برسشنامهها، رضايت دانشجويان جلب و زمان كافى براى بِاسخدهى به سؤالات به آنها

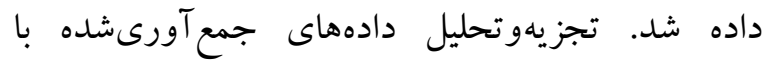
استفاده از نرمافزار SPSS ويرايش Yr و و آزمونهاى آمارى همبستخى ويرسون (سنجش همبستخى سلامت معنوى و روانى)، تى تست وآنوا استفاده شد. سطح

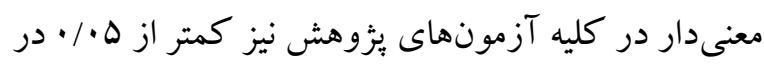
نظر كرفته شد.

يافتهها مشخصات دمو گر افيكك دانشجويان نشان داد كه بيشترين

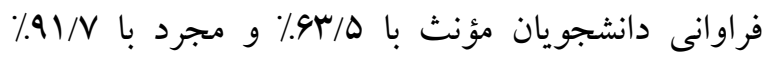

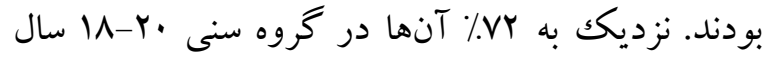
قرار د داشتند. هN/9٪ افراد موردمطالعه بومى استان كردستان بودند. طبق جداول (او كوب) افراد موردمطالعه

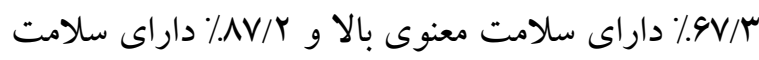

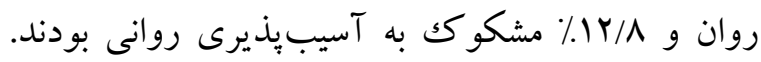

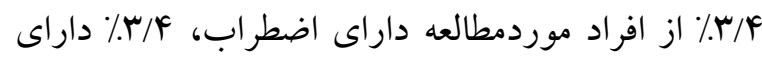

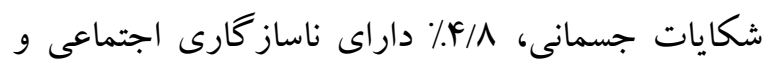

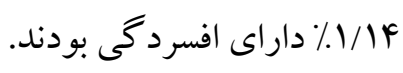

طبق جدول شماره | بيشترين فراوانى سلامت معنوى در افراد موردمطالعه در ردهبالا با س/9V/ است و همجنين،

\footnotetext{
${ }^{3}$. Palahang H, Nasr M
}

تعلق گرفت. در يايان نيز، سلامت معنوى به سه سطح

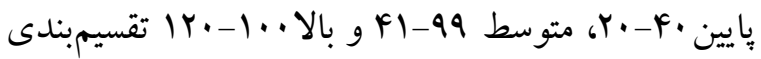
شد.

آزمون سلامت روان-'GHQ : اين خِرسشنامه داراى

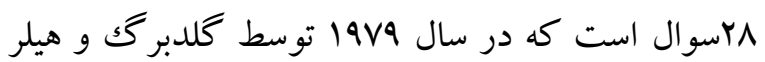
طراحى و تدوين شده است (كلدبرگك، 19V9) و داراى جهار مقياس است. مقياس Aعلائم جسمانى مانند احساس افراد نسبت به وضع سلامت خود، احساس خستخى و نشانهاى بدنى را دربرمى گيرد. مقياس احسى علائم اضطرابى همجون بى خوابى و مقياس Cلائم اختلال در كاركرد اجتماعى مثل توانايى افراد را در مقابله با خواسته هاى حرفهاى و مسائل زندگى روزمره و احساسات آنها را درباره موقعيتهاى متداول زندگى مولى آشكارمى كند. مقياس D نيز علائم افسردگى مانند افسردگى وخيم و گر ايش مشخص به خود كشى را شامل

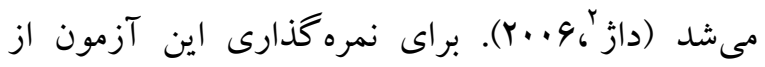

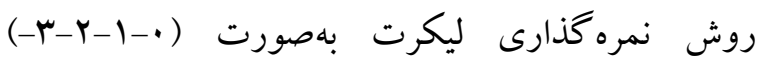
استفاده شد. درمجموع نيز نمره هر فرد در كل بين · تا لـ متغير است. در هر حيطه نيز دانشجويانى كه نمره آنها

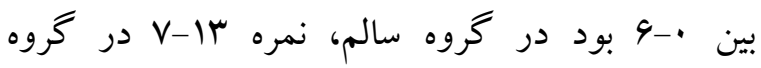
مشكوكك و نمره |r-Y| داشتند. بدين ترتيب با افزايش نمره سلامت عمومى، كيفيت سلامت روانى بايينتر مى آيد. بهعبارتديخر در برد اين مطالعه مانند ساير مطالعات (توكلى زاده، .1. (Y) جهت تعيين وضعيت دانشجويانى كه داراى مشكل و و اختلالات روانى مىباشند از نقطه برش بr استفاده شد، به اين صورت دانشجويانى كه نمره سلامت عمومى آنها بيش از بr به دست آيد بهعنوان مبتلابه اختلال روانى و

\footnotetext{
${ }^{1}$. General Health Questionnaire

${ }^{2}$. Daje A
} 
فراوانى زير مقياس سلامت روانى در افراد موردمطالعه با

بيشترين فراوانى سلامت روانى در افراد موردمطالعه

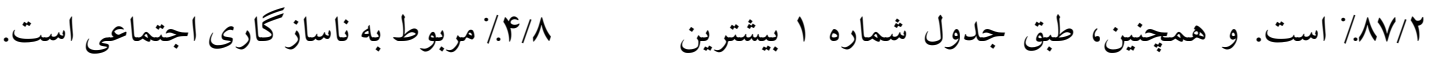

جدول ا توزيع فراوانى سلامت معنوى و سلامت روانى در افراد موردمطالعه

\begin{tabular}{|c|c|c|}
\hline درصد & فراوانى & سلامت معنوى \\
\hline$\% 1 / 9$ & $r$ & يإين \\
\hline$\%$ & If. & متوسط \\
\hline$\% .9 \mathrm{~V} / \mathrm{r}$ & rar & بالا \\
\hline
\end{tabular}

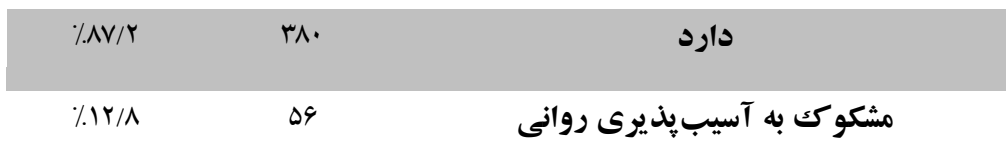

\section{خرده مقايس هاى سلامت روانى}

$\% / \mathrm{F}$

$\% / \mu$

$\%$. $/$ 人
10

10

r)

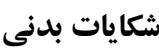

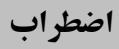

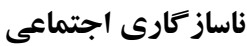

\section{$\% / / F$ \\ $\Delta$$$
\text { افسر دى }
$$

بين دو متغير سلامت معنوى و اضطراب برابر با سMI/ • و جدول Y نشان مىدهد كه ضريب همبستكى بين دو متغير بين دو متغير سلامت معنوى و افسردگى برابر با IYA • سلامت معنوى و سلامت روانى برابر با • •\&/• و بين دو است و رابطه بين دو متغيرها را نشان مىدهد. متغير سلامت معنوى و شكايات جسمانى برابر با MFV/ . و

\begin{tabular}{|c|c|c|c|}
\hline حجم نمونه & سطح معنادار بودن & ضريب همبستكى & متغير \\
\hline res & $\cdot / \cdots$ & $\cdot / F \Delta$. & سلامت روانى \\
\hline fra & $\cdot / \ldots$ & $\cdot / T F V$ & شكايات جسمانى \\
\hline frg & $\cdot / \ldots$ & . & اضطراب \\
\hline res & $\cdot / \ldots$ & - FIV & ناساز كارى اجتماعى \\
\hline Frq & $\bullet / \ldots$ & .1941 & افسردمى \\
\hline
\end{tabular}




$$
\begin{aligned}
& \text { جدول r بنشان مىدهد كه بين سلامت معنوى و سلامت }
\end{aligned}
$$

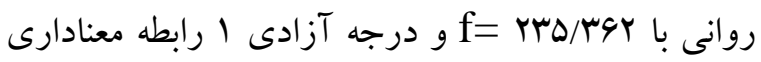

\begin{tabular}{|c|c|c|c|}
\hline سطح معنادارى & فراوانى & درجه آزادى & \\
\hline$\cdot / \cdots$ & rTD/rat & 1 & سلامت معنوى با سلامت روان \\
\hline$\cdot / \cdots$ & $\Delta q / 9 \vee q$ & 1 & سلامت معنوى با شكايات جسمانى \\
\hline$\cdot / \cdots$ & $19 T / Y \mu r$ & 1 & سلامت معنوى با اضطر اب \\
\hline$\cdot / \cdots$ & $91 / 1 \wedge$. & 1 & سلامت معنوى با ناساز كارى \\
\hline$\cdot / \cdots$ & $r A Y / \cdot D \Delta$ & 1 & سلامت معنوى با افسردحى \\
\hline
\end{tabular}

\begin{tabular}{|c|c|c|c|c|c|c|c|}
\hline حد يايين & حد بالا & $\mathbf{P}$ & انحراف استاندارد & تفاوت ميانكين & \multicolumn{2}{|c|}{ سلامت معنوى } & \\
\hline $19 / 49$ & $-1 / 19$ & $\cdot / \cdot \wedge$ & $\Delta / r \Delta$ & $9 / 10$ & متو سط & هايين & سلامت روان \\
\hline TV/GY & $\mathrm{V} / \mathrm{II}$ & $\cdot / \cdot \cdot 1$ & $\Delta / r Y$ & IV/rV & 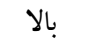 & & \\
\hline $1 \cdot / \cdot r$ & $9 / 4$. & $\cdot / \cdot \cdot 1$ & $\cdot / 9 r$ & $\Lambda / Y)$ & 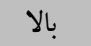 & متوسط & \\
\hline$\Delta / A \vee$ & $-1 / T \Delta$ & $\cdot / r$ & $1 / \wedge 1$ & 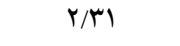 & متو سط & هايين & شكايات جسمانى \\
\hline V/TI & • &.$/ . F$ & $1 / \wedge$ & $r / \mathrm{rV}$ & 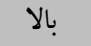 & & \\
\hline$r / .9$ & $\cdot / \Lambda \mu$ & $\cdot / \cdot \cdot 1$ & ( & $1 / 49$ & 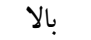 & متوسط & \\
\hline$f / 91$ & $-r / 91$ & $\cdot / \Delta \Delta$ & $1 / 91$ & $1 / 10$ & متو سط & هايين & اضطراب \\
\hline$V / F \Lambda$ & $\cdot / \cdots 1$ & $\cdot / \cdot 0$ & $1 / 9$ & $r / V F$ & 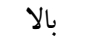 & & \\
\hline$r / r \Delta$ & 1/9 & $\cdot / \cdot \cdot 1$ & $\cdot / M F$ & $r / \Delta q$ & 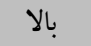 & متوسط & \\
\hline$\Delta / F F$ & $-1 / \cdots$ & $\cdot / \Lambda$ & $1 / 94$ & Y/YY & متوسط & هإيين & ساز Fارى اجتماعى \\
\hline V/RT & $\cdot / 9 r$ & $\cdot / \cdot 1$ & $1 / 94$ & $F / I r$ & 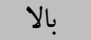 & & \\
\hline$T / F V$ & $1 / \mu F$ & $\cdot 1 \cdot \cdot 1$ & $\cdot / 49$ & $1 / 9$ & 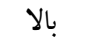 & متوسط & \\
\hline $9 / Y Y$ & $\cdot / \mathrm{Vr}$ & $\cdot 1 \cdot 1$ & $1 / 4$ & $r / F V$ & متوسط & هايين & افسردگى \\
\hline $1 / 49$ & $r / 99$ & $\cdot / \cdot \cdot 1$ & $1 / \pi 9$ & $\Delta / N r$ & بالا & & \\
\hline$r / V F$ & $1 / \mathrm{WV}$ &.$/ \cdot 1$ & $\cdot / T \Delta$ & T/YG & بالا & متوسط & \\
\hline
\end{tabular}

كزارش كردند وضعيت دانشجويان در دو مؤلفه سلامت معنوى و روانى مناسب است يثزوهش حاضر نيز نشان داد نتايج حاكى از اين مسئله بود كه اكثريت دانشجويان در كه در ابعاد سلامت روانى اكثريت دانشجويان داراى هر دو مؤلفه سلامت معنوى و سلامت روانى در وضعيت وضعيت سالم روانى بودند. از سوى ديخر هر جه ميزان بالايى قرار داشتند كه وضعيت مناسبى است اين يافته سلامت معنوى در افراد بالاتر و قوىتر باشد، ميزان همسو با يافتهاى بالاهنگ بـ و ناصر (199V) است كه 
شاخصهاى سلامت روان ازجمله رضايت از زندگى،

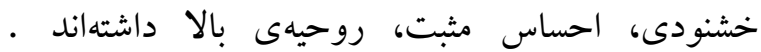
يافتهاى اين تحقيق همجنين با نتايج بُزوهش (اميدوارى،

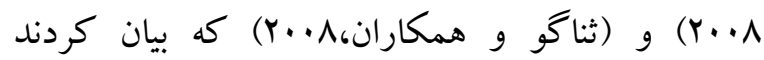
معنويت با سلامتى، احساس خوب داشتن و بهبودى

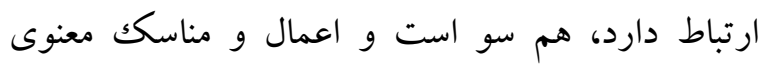
روزانه، حمايت مذهبى و خود ارزشيابى مذهبى معنوى در زندكى فرد مىتواند بهشدت و بهطور معنادارى ييشيينى

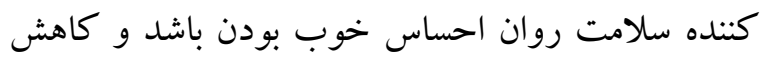
ميزان سلامت معنوى را در فرد، با نوعى احساس فشار روانى، اضطراب، افسردگى و تنهايى همراه دانستهاند. بلبيانديخر نخستين اثر ارتقاء توانمندىهاى فرد درزمينه سلامت معنوى قدرت حاصل از مذهب، كاهش

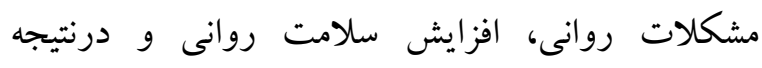
افزايش سبكهاى رفتارى سالم، هيجانات مثبت و خوشينى و رضايت از زندگى خواهد بود.

\section{نتيجه كيرى}

يافتهاى ئوهش نشان داد كه بين سلامت روان بان سلامت معنوى در دانشجويان ارتباط مثبت معنادارى وجود دارد. بهعبارتديخر مىتوان گفت كه هرجه ميزان سلامت معنوى در دانشجويان بالاتر و قوىتر باشد، ميزان آسيبهاى روانى در آنها كمتر خواهد بود. همجنين

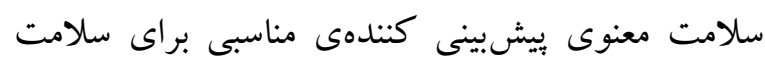

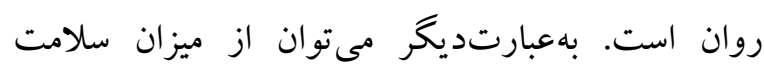

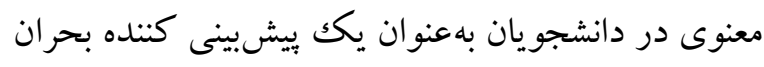
روانى در آنها استفاده كرد از آنجايى كه تعداد زيادى از نمونهاى مورديُّوهش از سلامت معنوى خوبى ردادي برخوردار بودهاند، مىتوان طراحى مداخلات در جهت حمايت معنوى از آنان را انجام داد.
آسيبهاى روانى در آنها كمتر خواهد بود؛ بنابراين مىتوان از سلامت معنوى در دانشجويان بهعنوان يك دان يشينى كننده بحران روانى استفاده كرد. يافتهاى

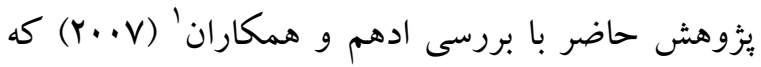

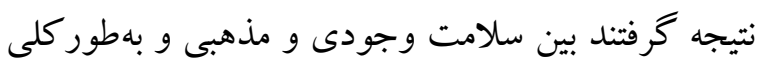
سلامت معنوى با سلامت روانى و زير مقياسهاى آن (شكايات جسمانى، اضطراب، ناساز كارى اجتماعى و افسردگى) رابطه معنادارى وجود دارد همسويى وجود إناري

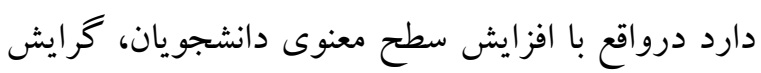
آنها در جهت بهبود سلامت روان نيز افزايش داشته

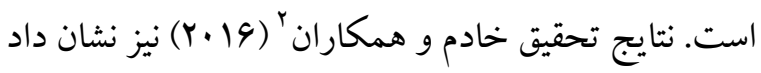
كه بين سلامت معنوى و سلامت روان دانشجويان

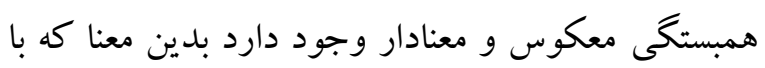
افزايش ميزان سلامت معنوى، ميزان استرس، اضطراب و

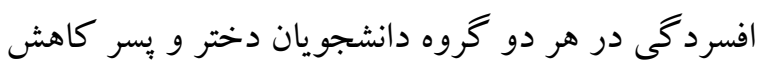
مىيافت. بر طبق يُروهش محققين دانشكاه هاروارد، معنويت نهقطط ريشه در عقيده فرد داشته بلكه ريشه در تجربه او نيز دارد. اخر شخصى فقط اعتقاد داشته باشد رلد ولى تجربه نكرده باشد، بسيارى از فوايد جسمى و روانى معنويت را از دست مىدهد. ممكن است بسيارى از افراد تجارب معنوى داشته باشند، ولى آن را نشناسند (كارن و

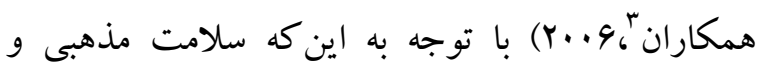
سلامت وجودى، دو بعد اصلى تشكيلدهنده سلامت معنوى هر فردى هستند نتايج اين تحقيق در اين زمينه نشان مىدهد كه نمره سلامت مذهبى دانشجويان، بالاتر از

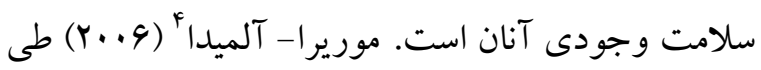
يُووهى نشان داد كه رفتارهاى مذهبى رابطه معنادارى با ليا

\footnotetext{
1. Adham D et al.

2. Khadem, H et al.

${ }^{3}$. Karren KJ et al.

4. Moreira-Almeida
} 
Karren KJ, Hafen BQ, Smith NL, Frandsen KJ. (2006). Mind-body health: the effects of attitudes, emotions, and relationship. 3th Edition, Pearson: Sanfrancisco.

KavoosianN, HosseinzadehK, Kazemi JalisehH, KarboroA. (2018). The Relationship between Spiritual Health and Loneliness among the Elderly in Karaj- 2016. J Res Relig Health. 4(2): 7- 15 .

Khadem, H. Mozafari, M. Yousefi, A. Ghanbari Hashemabad, B. (2016). The relationship between spiritual health and mental health in students of Ferdowsi University of Mashhad. J Med History. 7(25): 33-50.

Knapik GP, Martsolf DS, Draucker CB, Strickland KD. (2010). Attributes of spirituality described by survivors of sexual violence. Qual Rep. 15(3):644-657

Moreira-Almeida. (2006). Religiousness and Mental Health: a review, Center for the Study of Religious and Spiritual Problems (NEPER), São Paulo (SP), Department of Psychiatry,Universidade de São Paulo(USP).

Omidvari S. (2008). Spiritual health; concepts and challenges. Quranic Interdisciplinary Studies Journal of Iranian Students Quranic Organization. 1(1) 6-17

Palahang H, Nasr M. (1997). A study of the epidemiology of mental disorders in the Kashan, Joumal of Andisheh \& Raftar, 2 (4): 19-27 [Persian].

Paloutzian, R. F. \& Ellison, C. W. (1982). Spiritual wellbeing scale. In P. C. Hill \& R. W. Hood (Eds.), Measures of religiosity. Birmingham, AL: Religious Education Press. p. 382-385.

Rezaei M, Adib-Hajbaghery M, Seyedfatemi N, Hoseini F. (2008). Prayer in Iranian cancer patients undergoing chemotherapy. Complementary therapies in clinical practice. 14(2):90-7.

Sadri M. (2003). The effect of trust in God to provide mental health of students 23-19 years of Isfahan. Behav Sci J. 1 (2):43-6.

Sanagoo A, AliGhoodneh Z, Asadi H. (2008). The relationship between spiritual health and loneliness between the Persian and Turkmen

$$
\begin{aligned}
& \text { سياسگزارى } \\
& \text { اين بثرهش با حمايت مالى معاونت تحقيقات و فن آورى }
\end{aligned}
$$

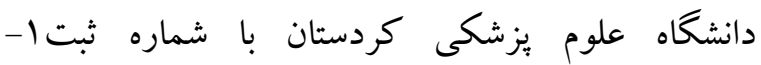

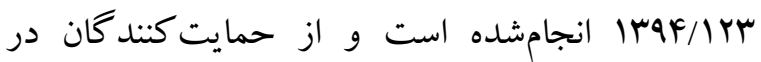

$$
\begin{aligned}
& \text { اجر اي اين يُوهش كمال تشكر و قدردانى را دارم. }
\end{aligned}
$$

\section{References}

Adham D, Salem Safi P, Amiri M, Dadkhah B, Mohammadi M, Mozaffari N, et al. (2008). The Survey of Mental Health Status in Ardabil University of Medical Sciences Students in 2007-2008.

Adib-Hajbaghery M, Faraji M. (2015). Comparison of happiness and spiritual well-being among the community dwelling elderly and those who lived in sanitariums. Int $\mathbf{J}$ Community Based Nurs Midwifery. 3(3):216-26.

Daje A. (2006). [Investigate of high school students with health problems in the Kohkiluyeh city] [Master thesis]. Isfahan: Isfahan University. (Persian)

Ghaderi A, Tabatabaei SM, Nedjat S, Javadi M, Larijani B. (2018). Explanatory definition of the concept of spiritual health: a qualitative study in Iran. JMed Ethics Hist Med. 11:3.

Goldberg DP, Hillier VF. (1979). A scaled version of genteral health questionnaire. Psychological Medicine; 9: 131-145.

Hematti S, Baradaran-Ghahfarokhi M, Khajooei-Fard R, Mohammadi-Bertiani Z. (2015). Spiritual well-being for increasing life expectancy in palliative radiotherapy patients: a questionnaire- based study.J Relig Health. 54(5):1563-72

Hilton JM, Child SL. (2014). Spirituality and the successful aging of older Latinos. Counseling and Values. 59(1):17-34.

Hosseini S.A. (1995). Fundamentals of mental health. Iran, Mashad: Mashad University Pub.

Jirasek I. (2015). Religion, spirituality, and sport: from religio athletae toward spiritus athletae. Quest. 67(3):290-9. 
youth. Research Center of Gorgan University of Medical Sciences.(Persian)

Tavakolizadeh J, Khodadadi Z (2010). Assessment of Mental Health Among Freshmen Entering the First Semester in Gonabad University of Medical Sciences in 2009-2010. Ofogh-eDanesh. 16(2): 45-51 [Persian].

Young C, Koopsen C. (2005). Spirituality, health and healing. 1st Edition, Slack Incorporated: California. 